\title{
Conceptualising the Impact of Initial Teacher Education
}

\author{
Fiona Ell \\ The University of Auckland \\ Alyson Simpson \\ The University of Sydney \\ Diane Mayer \\ The University of Sydney \\ Larissa McLean Davies \\ The University of Melbourne \\ Janet Clinton \\ The University of Melbourne \\ Georgia Dawson \\ The University of Melbourne \\ Corresponding author: \\ Fiona Ell \\ f.ell@auckland.ac.nz \\ DDI: + 6496238899 \\ EXT: 89847
}




\title{
Conceptualising the impact of initial teacher education
}

\begin{abstract}
In the current context, where global comparative education testing plays an increasing role in education policy and teacher quality is identified as a key to economic performance, initial teacher education has become a focus of concern and reform. Questions are asked about the impact of university-based teacher preparation, and 'alternate routes' into teaching emerge. Currently, in Anglophone countries, there is a turn towards practice and away from preparation that is seen as overly theoretical. In this paper we propose a conceptual model of initial teacher education impact that examines the breadth of ways in which university-based teacher education impacts on the education system, positioning initial teacher education as more than just a source of newly-qualified teachers. Using a complexity thinking framework, this paper offers a nuanced way to conceptualise initial teacher education impact that acknowledges the integrated nature of the education system and the way in which all stakeholders work together to improve student learning.
\end{abstract}

Keywords: initial teacher education, student learning, complexity theory

\section{Introduction}

Despite critiques of large-scale testing (Meyer 2013), concerns about declining country rankings in comparative international assessments such as PISA have prompted governments in many Anglophone countries to implement large-scale reform agendas designed to improve teacher quality with the hope of achieving higher rankings (Gillis et al. 2016). Integral to these reforms are accountability mechanisms designed to focus attention on student learning in order to make judgements about teacher effectiveness as well as the effectiveness of teacher education programmes (Coggshall et al. 2012; Day and Gu 2014). A key policy mechanism has been to require initial teacher education programmes ${ }^{1}$ to demonstrate evidence of their impact both on pre-service teacher learning and school students' learning. In countries such as the United States (Council for the Accreditation of Educator Preparation 2018; Cochran-Smith et al. 2016), New Zealand (Education Council of New Zealand 2016), Australia (Australian Institute for Teaching and School Leadership 2015), and the United Kingdom (Menter et al. 2010; DfE 2013), the imperative to demonstrate that initial teacher education programmes are able to impact on school students' learning has been leveraged by perceptions of the inadequacy of research evidence regarding the efficacy of initial teacher education programmes (e.g. Sleeter 2014; Murray et al. 2008; Rowan et al. 2015).

\footnotetext{
${ }^{1}$ In this paper, initial teacher education is understood as university-based teacher education which is completed prior to teaching, this being the dominant model of teacher education in Australasia.
} 
The aims enshrined in policy and the mechanisms embedded in accountability requirements often assume a linear and causal relationship between initial teacher education programmes and student learning as measured by standardised tests, such as the Value-Added Modelling approaches in the United States (Darling-Hammond 2015; Loeb and Candelaria 2012). It is indisputable that enhanced student learning should be the ultimate aim of the education enterprise of which teacher education is a part, and that graduate teachers should be able to enter the profession with the knowledge, skills and dispositions required to positively impact on student learning. However, the assumption that there is a direct, linear and causal relationship between the initial teacher education programme and the learning of students taught by initial teacher education graduates as they take up their career trajectories fails to acknowledge and capture the complexity of the situated nature of initial teacher education in education systems (Hayes and Doherty 2017; Cochran-Smith and Zeichner 2005; Cochran-Smith et al. 2014; Davis and Sumara 2006; Grossman and McDonald 2008; Mayer et al. 2012; Rowan et al. 2015). As a result, a limited conception of impact is enacted that fails to capture the multiple variables contributing to student learning in a multi-faceted, integrated system. This type of single-solution approach does nothing to inform understandings about how change and growth in student learning comes about, which means that reform efforts based on single-solution approaches are unlikely to lead to large-scale change in student learning. Moreover, it neglects any consideration of other impacts initial teacher education may have within the education enterprise, all of which, over time and in total, can impact student learning.

In this paper, we challenge the notion that the effectiveness of teacher education can be judged unproblematically by the impact of its graduates on student learning. This is not because we believe that student learning does not or should not matter for teacher education, but rather because it does matter in very significant ways. It matters to such a degree that it renders the current singularly directed and causally framed solution informing accountability inadequate (Furlong 2015). We argue that initial teacher education is an integral part of education and schooling, rather than an 'input' to the wider education system. As an integral part of the education system, initial teacher education impacts student learning in ways that are diffused throughout the interconnected elements of education and schooling. We interrogate the complexities of initial teacher education programmes, and the governmental and educational systems of which they are a part, to build a conceptual model for analysing the impact of initial teacher education. This model can then be used to inform policy agendas, as well as to further enrich research on the effectiveness of teacher education and suggest ways to improve student learning.

Others before us have supported the value of adopting complexity as a lens through which initial teacher education may be viewed (Cochran-Smith et al. 2014). We argue for thinking about teacher education as a complex system, not a complicated system (Davis and Sumara 1997). Unlike complicated systems, complex systems cannot be broken down into parts in order to be understood and linear cause and effect thinking, simplification and picking apart of processes or problems cannot result in deep understanding of, 
or improvement in, system functioning (Cilliers 1998). Seeing initial teacher education as a complex system contrasts with a view of initial teacher education as an entity separate from schooling and policy that acts only as a supplier of graduate teachers to the system itself. As a complex system, initial teacher education is fundamentally integrated with all other parts of the education system - students, schools, ministries, professional developers, and communities, for example - in ways that create significant interactions and outcomes. Using complexity theory to understand how education functions provides researchers with insights that are not apparent when linear ways of thinking are used (Davis and Sumara 2006). Complexity theory is fundamentally a theory that seeks to understand how complex systems function, providing explanations for why unexpected consequences sometimes occur, why small changes might lead to large effects and why interventions may fail to make an impact (Byrne 1998; Mason 2008; Morrison 2008). Complexity theory focuses on emergent phenomena, and pays attention to the interactions and feedback mechanisms that occur within a complex system because seeing how things work together is critically important in understanding complex system functioning (Anderson, Crabtree, Steele \& McDaniel 2005; Hetherington 2013; Morrison 2008). Complex systems are full of interdependencies and contingencies, the effects of which are non-random but unpredictable (Byrne 1998; Cilliers 1998; Waks 2011). This means that a deep understanding of the parts and processes of a system is a necessary precursor to understanding how change in that system might occur (Davis \& Sumara 2010; Ovens 2017).

Much of what has characterised policy thinking to date suggests a complicated systems approach whereby teacher education has been taken apart and the component pieces have been examined with the assumption that by examining the pieces one can understand the whole system and its functioning. In this way, various reform agendas have been promulgated focusing on one component part and providing a solution for that part of the whole with the assumption that the whole is the sum of its parts - fix one part and the entire enterprise of teacher education can be fixed. However, drawing on complexity theory, "if a complex system is taken apart, key aspects of how the system works and what makes it work in the first place are lost since unexpected consequences arise as a result of the dynamic interaction of parts" (Cochran-Smith et al. 2014, p.107). So, when teacher education is thought of a complex system, we acknowledge the multiple parts and interactions, but also acknowledge that the whole is more than the sum of its parts. Trying to reform component parts may lead to unintended consequences, and inevitably does not create substantive, sustainable or desired change because of the complex nature of the education system. In addition, the role that initial teacher education plays in the education system can be underestimated when it is seen as a 'supplier' of component parts (e.g. teachers) rather than an integral part of the wider system.

\section{Developing an alternative model of initial teacher education impact}


In the first section of this paper we have described why linear, causal explanations for the impact of initial teacher education on student learning are inadequate and how policy directions that position initial teacher education as a direct lever on increasing students' achievement scores have had little success in providing better outcomes for learners (Cochran-Smith and Villegas 2015; Ellis and Moss 2004; Cormack and Comber 2013; Polesel et al. 2012). In this section, we propose a conceptual model to help policy makers, researchers, evaluators and practitioners think about the impact of initial teacher education in a different way. The model is underpinned by three key assertions about initial teacher education and its impacts: first, linear models cannot explain the impact of initial teacher education because it is fundamentally complex; second, student learning does not occur in a void, rather it is nested in a set of interconnected complex systems that together comprise the 'education system' of which initial teacher education is one part; and third, initial teacher education is more than just its graduates - it comprises researchers, teacher educators and different programmes, all of which can impact student learning. We propose a model where initial teacher education can be seen to have multiple impacts and incorporate multiple mechanisms for impact, in contrast to policies such as those in the United States, which measure student learning gains on standardised tests in the classrooms of newly graduated teachers, and use this as the sole measure of the teacher preparation programme's effectiveness (Cochran-Smith et al 2016).

The conceptual model we present resulted from several structured workshops where representatives of three initial teacher education providers (from New Zealand and Australia) attempted to map the impacts of their work using the linear logic of current policy discourses and shared the ways in which each provider currently evaluated impact. These discussions revealed our common concern about what was being missed when simplified notions of impact were used as measures for initial teacher education effectiveness. Thus, we began to build an alternative logic, predicated on the inherent complexity of education and an understanding of how initial teacher education contributes to the wider education system. The conceptual model presented and discussed in this paper emerged from this work. Our purpose in proposing the conceptual model is not to explain or describe initial teacher education and its impacts in full, but rather to suggest a conceptual tool that might help policy makers, researchers and practitioners see and evaluate initial teacher education impact in new and productive ways. Our goal in this paper is to stimulate discussion about the utility of the model in capturing the complexity of initial teacher education impact. For this reason it adopts a discursive style that rests on experimental propositions exemplified by holistic narratives representing grounded empirical support.

\section{The conceptual model}

The conceptual model (Figure 1, below) represents three key ideas about initial teacher education and its impact on student learning. First, student learning is embedded in, and emerges from, a number of overlapping complex systems, rather than being an outcome or product of a process. This means that impact on student learning might occur at the level of teachers, their knowledge and practice, or at the 
level of education policy, as well as the students themselves. Second, initial teacher education intersects with the systems from which student learning emerges. This means that the impact of initial teacher education is not found in just one place (for example, in teacher candidates' work with students) but, for example, also in consultancy on policy, professional development of mentor teachers, and the generation of new knowledge about teacher learning through research. Third, initial teacher education is not a uniform phenomenon consisting of a single pathway or defining component. Measuring the impact of initial teacher education on the education system by just considering the achievement scores of school students in newly qualified teachers' classes misses the less visible, but sometimes more direct, impacts of initial teacher education on the learning of students. Initial teacher education programmes can affect schools and teachers, and therefore the conditions for student learning, through the professional relationships of their teacher educators, through the programme structures and arrangements they design, through the research they generate, and through their advocacy and 'critic and conscience' role. The relationships and structures are designed to support teacher candidates' learning, but they often have other effects on teachers and schools that can impact student learning. A complex view draws attention to these effects and regards them as important. For example, programmes that partner university faculty members with mentor teachers in schools can be a source of professional learning for faculty and school staff. This happens regardless of the progress of the teacher candidates in the school but would not happen if the school was not engaged with the university in initial teacher education. This reciprocal learning can enhance school practices and research and teaching in the university, resulting in better outcomes for students (for example through improved teaching practice, implementation of the findings of research and increased authenticity in university teaching). If teacher education institutions were removed from teacher preparation these more hidden impacts would be lost. This conceptualisation of initial teacher education, based on ideas of complexity, draws attention to the idea that initial teacher education's contribution extends beyond being a 'graduate factory' that exists separate from the education system and has no impacts other than its 'products'.

Each of these key ideas - student learning is embedded in overlapping complex systems, initial teacher education intersects with the systems in which student learning is embedded, and initial teacher education has many components that might impact student learning - is represented visually below in Figure 1. In the next sections the model is broken down into its component parts in order to explain and exemplify it further. This piece-by-piece explanation is followed by two examples from Australian teacher education programmes that illustrate how the conceptual model can help understand and evaluate the impact of initial teacher education on student learning, taking into account the broader role initial teacher education plays in education systems. 


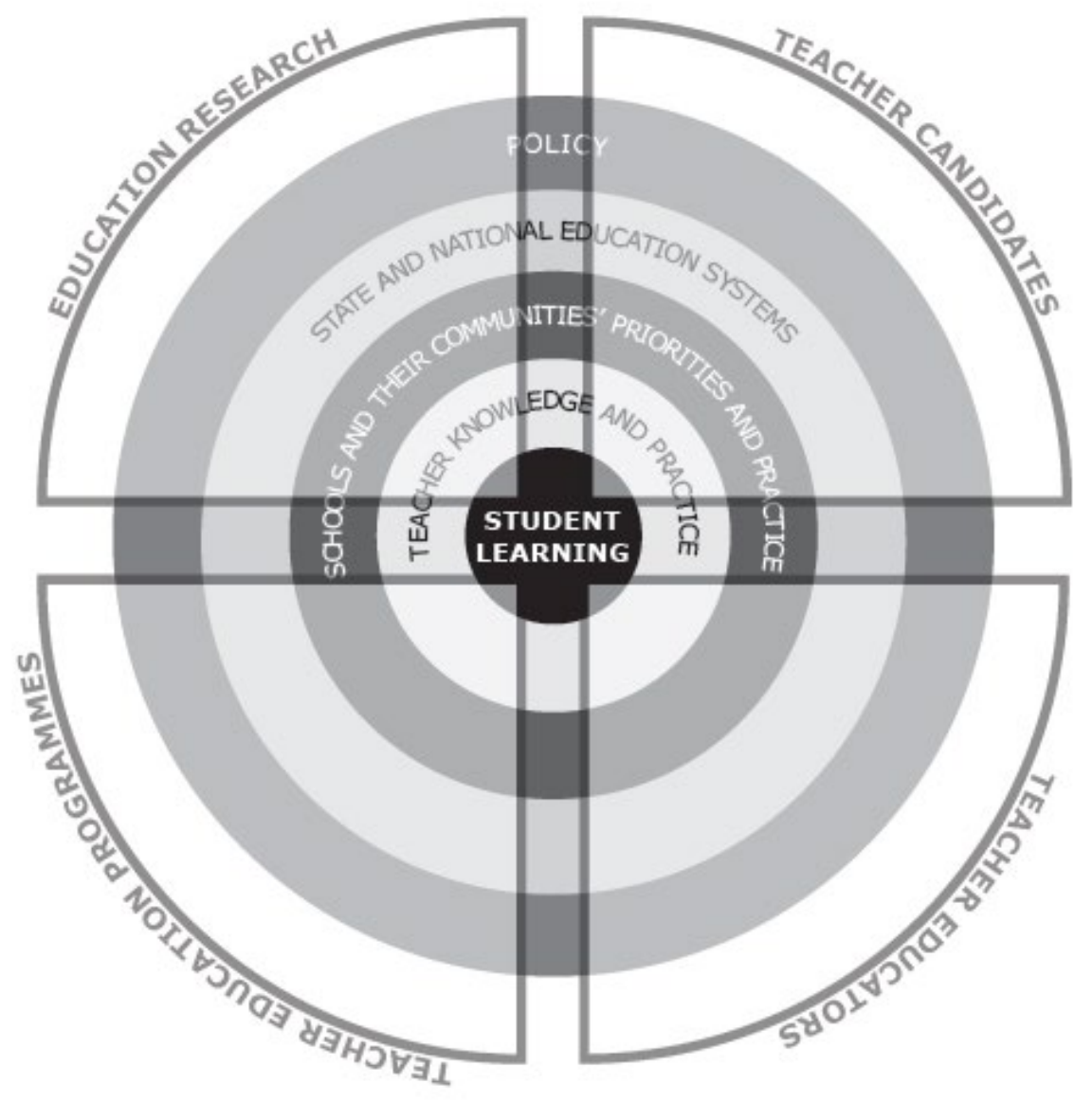

Figure 1: Model of initial teacher education impact

Concept 1: Student learning emerges from complex systems, rather than being a product of a linear process

The concentric circles in Figure 2 represent the series of complex systems of which student learning is the ultimate focus. In complexity terms, student learning emerges from these systems in an unpredictable but non-random way (Cochran-Smith et al. 2014). The conditions established by the agents and structures in each system shape the emergence of student learning by making some things more possible than others. These systems are overlapping rather than necessarily nested as they are represented here, and may have other goals alongside student learning. Seeing these systemic structures as surrounding student learning in this way is helpful, however, because it suggests how each 
complex system (a school for example) has its functioning shaped by larger systems (the educational system in which the school exists) and in turn shapes the systems that it surrounds (for example, resourcing teachers in certain ways, requiring assessment of some aspects of learning and not others, setting a school tone). The concentric circles make it clear that, while the most direct engagement with student learning occurs between teachers and students, there is a series of ever larger systems that have student learning at their centre, or as their reason for being, and that these systems can also act in ways that influence student learning. For example, a policy-level decision that literacy intervention programmes will be funded for students who meet certain requirements will be enacted through those state or national bodies responsible for distributing the resource to schools, who will appoint teachers to work with the students, whose learning should, in turn, be impacted. Intervention at any of these system levels could alter the efficacy of the policy (Comber and Freebody 2013). For example, the development of a new assessment to better reveal students' learning strengths and needs, professional development work with teachers on how best to tackle the students' next steps, or improved leadership practice that increases motivation to implement new programmes could all impact student learning. This example is simplified in order to illustrate how the idea of impact on student learning can occur in other spaces as well as face to face in classrooms. In reality, the linearity implied by this example is not present. Education is rife with unintended consequences and the apparent inability of locally effective ideas for improving student learning to work at scale (Elmore 2016; Fullan 2016). This is why we claim that these systems are fundamentally complex. Claiming complexity is not an abdication of professional agency, however, as feedback within the systems means that actions can have unpredictably large effects as well as surprisingly small ones. 


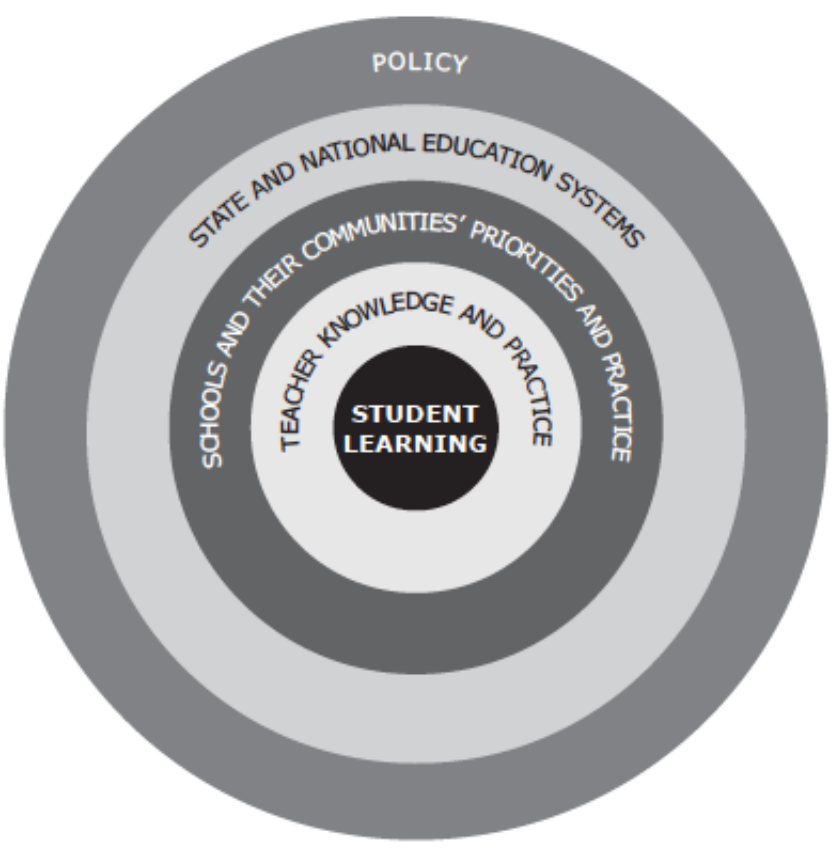

Figure 2: The foundation of the conceptual model: student learning within a series of complex systems

Concept 2: Initial teacher education intersects the complex systems from which student learning emerges

Where does initial teacher education fit in these systems that surround student learning? It does not make sense to include initial teacher education as one of the concentric circles, as it does not meaningfully surround students, schools or policy environments and yet it intersects with all of these things. It could be conceptualised as an adjacent circular system, overlapping in part with each of the concentric circles in Figure 2 above. We propose a different conceptualisation, however, which is that initial teacher education can better be seen as an overlay on all the layers in Figure 2. This aligns with the policy idea that student learning should be the key focus of initial teacher education (Cochran-Smith, 2016), while implying that initial teacher education impacts student learning across the layered and overlapping systems that also exist to improve student learning. Rather than being separate, at its best initial teacher education is fundamentally integrated with the other parts of the education system.

Thus in Figure 3, a circle representing initial teacher education is superimposed on the systems from which student learning emerges. The overlay of initial teacher education on these systems is intended to represent the intersection of initial teacher education with each of the systems. Initial teacher education is 
present in each of the systems represented by the concentric circles, including a direct intersection with student learning. In addition, involvement with initial teacher education at any of the system levels can have an impact on student learning. For example, if a teacher becomes a mentor teacher and has a teacher candidate working with them for several weeks they may interrogate their own practice more through explaining their decisions to the teacher candidate, or may notice more about student learning through having the teacher candidate ask questions or work with individual students. Partnering closely with an initial teacher education provider may be a significant move for a school, bringing new levels of discussion about practice and deeper scrutiny of student learning (McLean Davies et al. 2017; Kameniar et al. 2017; Simpson 2016). Teacher educators may also be curriculum experts who are called on to consult on state or national policies. These brief examples show that while initial teacher education shares the common goal of improved student learning with the other systems in Figure 3 , it can work across all levels to have impact as it intersects with each system in different ways. Thinking of the influence of initial teacher education on student learning as occurring at a range of levels within the complex education systems surrounding students opens up a range of ways to consider initial teacher education impact. Newly qualified teachers' skills and knowledge are not the only tangible impact of university-based initial teacher education: there are also, for example, partnerships with schools, growth of educative mentors, professional learning of school staff, and the production of research about a range of education issues, all of which can improve student learning. These impacts are occurring in all the layers of the overlapping systems shown in Figure 2. 


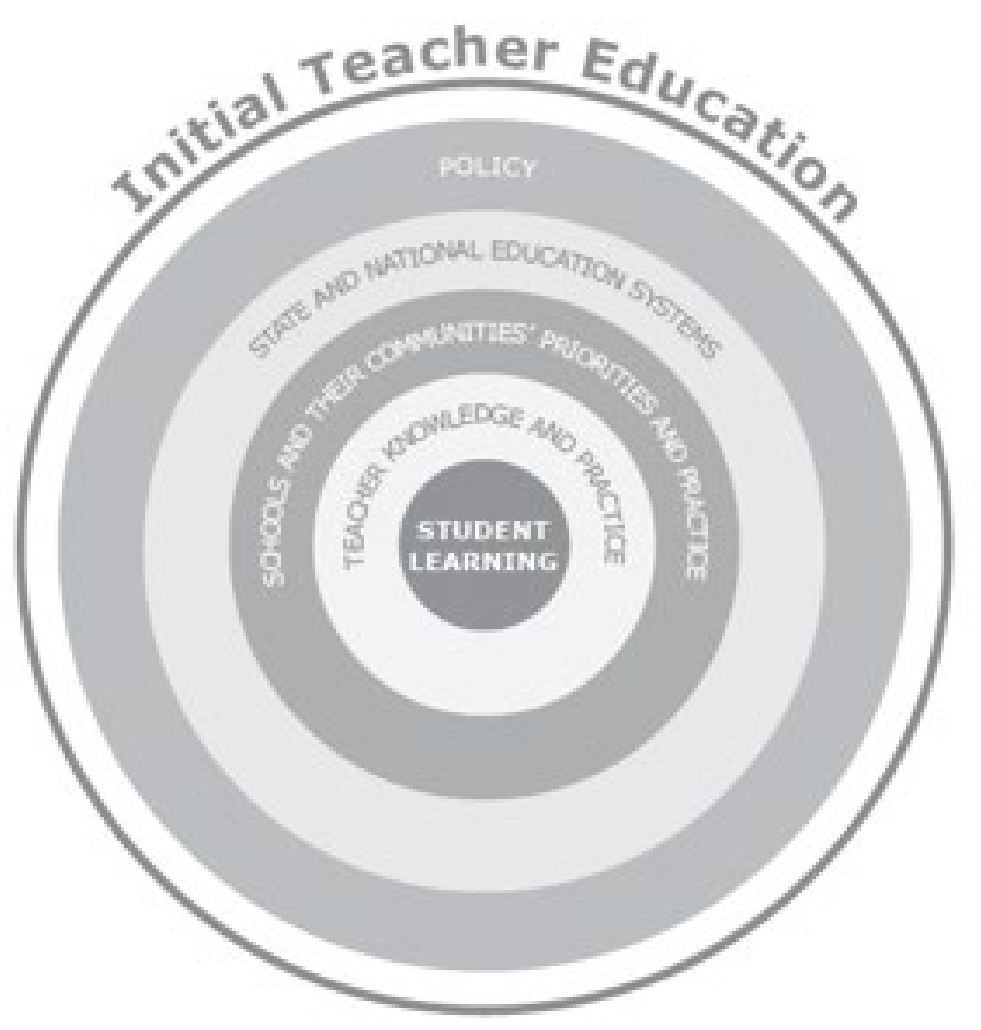

Figure 3: Initial teacher education intersecting the complex systems from which student learning emerges

Concept 3: In terms of improving student learning, initial teacher education contributes in a range of ways

Evaluating the impact of initial teacher education by measuring the achievement scores of the students of recent graduates (Cochran-Smith et al, 2016) ignores the impact that other elements of initial teacher education can have on student learning. Policy makers and governments want 'value for money' from their investment in teacher preparation, and doubts about the usefulness of tertiary preparation have led to a proliferation of alternate route providers and school-led models, especially in England and the United States. Placing the teacher candidates in classrooms, without the costly infrastructure of initial teacher education in institutions has economic appeal and 'face validity' in terms of authentically 'doing the job' of teaching. Concept 3 in this model proposes, however, that in dismantling or bypassing tertiary models of initial teacher education, valuable impacts on student learning are lost. University-based initial teacher education comprises a number of components, both agents and structures, that can impact student learning: for example, teacher educators and researchers; professional supervisors; programmes with different arrangements, durations and requirements; and research into initial teacher education and other areas of education. In order to explain this concept we take up four components as examples: teacher 
candidates, teacher education programme structures, teacher educators, and education research. Each of these elements of initial teacher education interacts with each of the systems represented by the concentric circles to a greater or lesser extent. Figures 4-7 below divide the circle that represents initial teacher education into four quadrants, one for each of these four example components. Some examples of the impact of each component are briefly sketched in the section that follows, to tease out the implications of considering impact in this way.

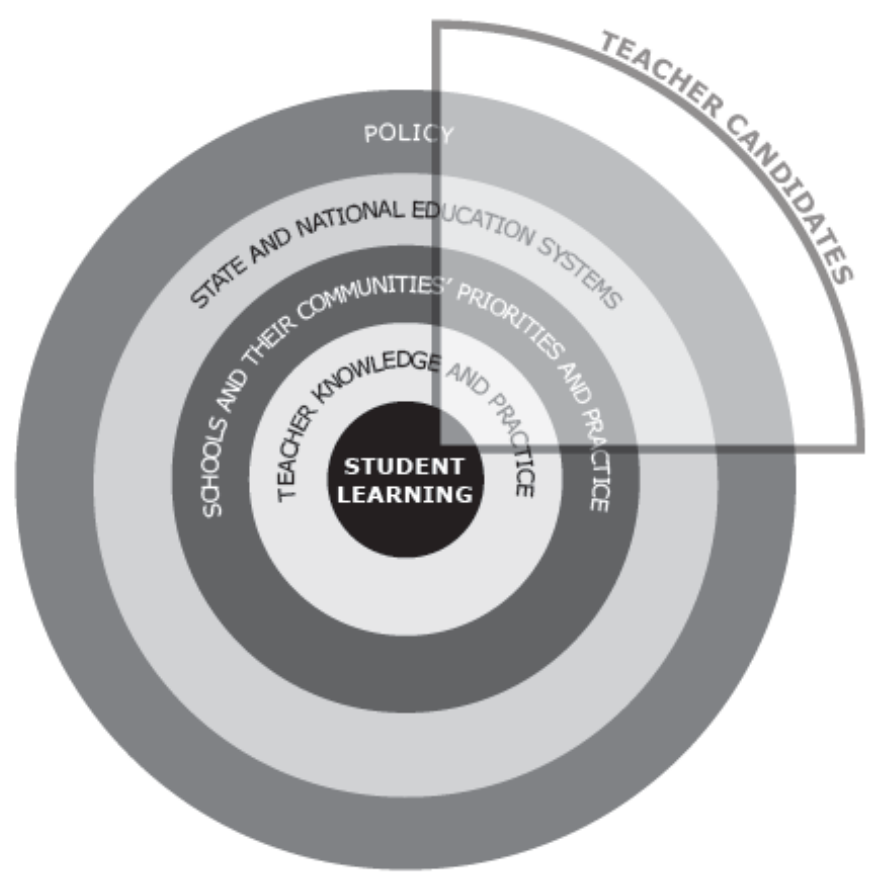

Figure 4: Teacher candidates' impact on student learning

Teacher candidates impact student learning when they work with students in classrooms. The amount of impact they have is shaped by their skills and attitudes and by the length of time they are in schools, where they are in their preparation programme and the amount of agency granted to them by mentor teachers. They may also impact student learning in other, less direct ways: they may influence the practice of their mentors, either by their presence in the classroom or by bringing new ideas (McLean Davies et al. 2015), or they may contribute to the school and its community by bringing their skills in music, drama, sport and languages. Teacher candidates' impact on education systems and policy is less direct, but their collective characteristics and perceived competence contribute to regulations about entry to teaching, which is seen as a way to leverage teacher quality and hence student learning. 


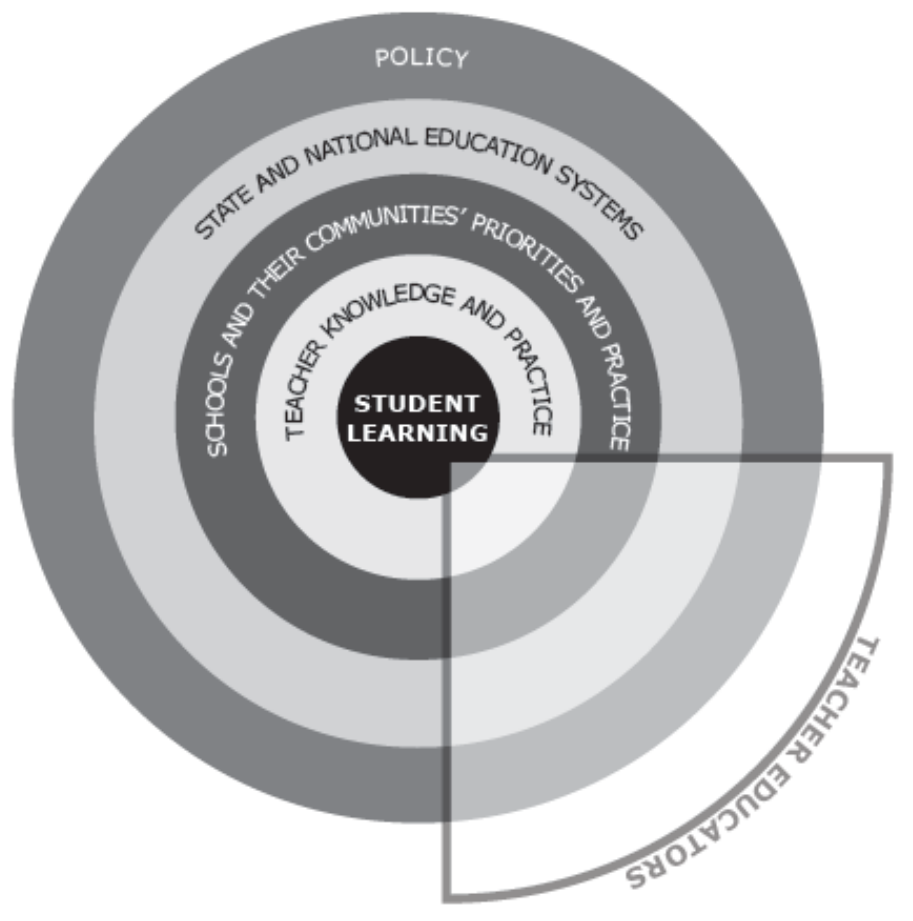

Figure 5: Teacher educators' impact on student learning

Teacher educators as individuals have an impact on the systems focused on student learning. For example, teacher educators' relationships and professional supervision work in schools, and their work as consultants to state and national groups and policy makers, impact student learning. Teacher educators may work with groups of teachers on curriculum issues, or participate in educative mentoring in ways that positively impact teachers' practice with students. When teacher educators work with schools and communities in innovative practicum arrangements, they can positively impact practice by forming new relationships with teachers and leaders, challenging practice together, and working with teachers and leaders to look more closely at practice (Grudnoff et al. 2017). 


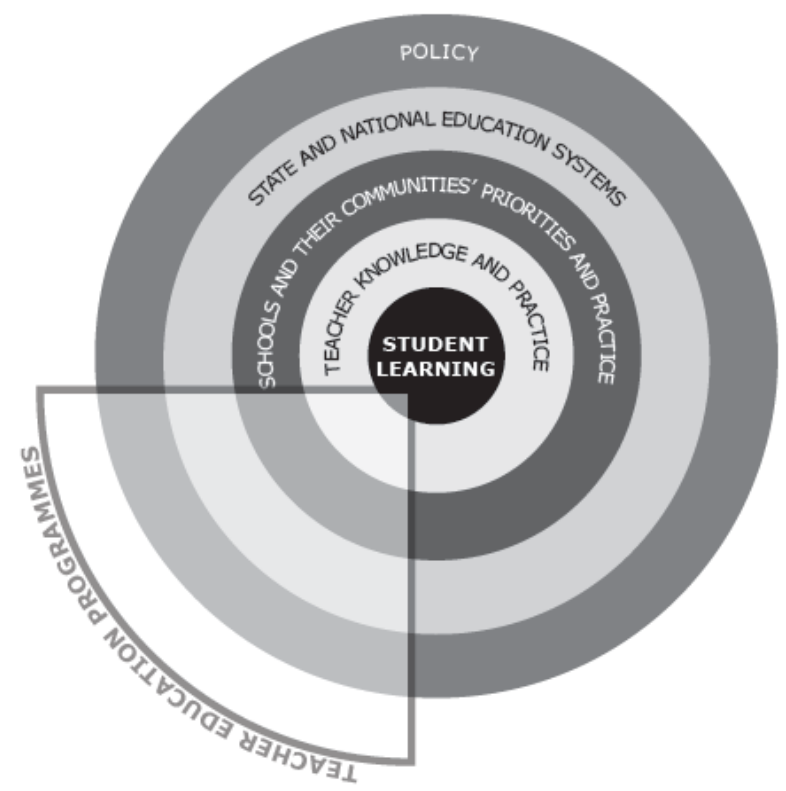

Figure 6: Teacher education programme structures' impact on student learning

Reforms in teacher education often focus on programme structure, suggesting that the way a programme is arranged can impact student learning. Programme arrangements include selection of teacher candidates, practicum length and objectives, teacher education curriculum, and the conceptual bases of the programme. These arrangements are designed to develop skills, knowledge and attitudes in teacher candidates that will allow them to lead student learning. Teacher education programme structures can impact in other ways too. For example, as part of an agenda to raise student achievement, the New Zealand government called for tenders for new 'exemplary' teacher education programmes. The resulting Masters-level qualifications have a focus on social justice through an inquiry approach and involve more time in schools than other preparation pathways. These programme arrangements demanded new relationships with schools and mentor teachers. Schools varied in their commitment to the Masters initiative, but in many cases their engagement with the initial teacher education programmes led to an interrogation of the school's data, professional discussion about how the school addresses social justice, and inquiry into practice alongside the teacher candidates. These actions are directed at improving student learning, and arose from engagement with initial teacher education at a programme level - the activity in the school was a result of coming to terms with the premises of the initial teacher education courses. 


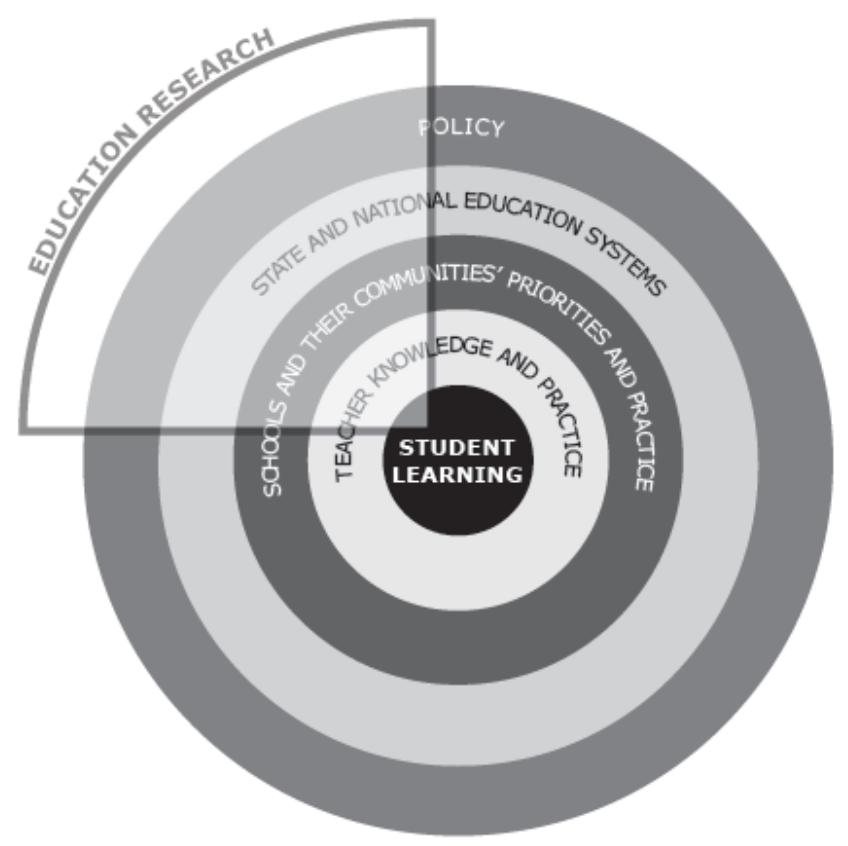

Figure 7: Education research's impact on student learning

The fourth and final quadrant represents a different type of impact: the impact on student learning of education research generated by teacher educators. Although the lack of impact from education research is often lamented, there is evidence of research-informed education policy and school-based decision making that uses the findings of education research. An example of this is the adoption of 'spirals of inquiry' (Timperley et al. 2014) as a school improvement model in Australia, New Zealand and Canada. Spirals of inquiry are centered on student learning and derive from research generated by teacher education providers. Another example involves research by teacher educators into mathematics education practices that support marginalised learners in New Zealand, which has led to improved student learning in the schools where these practices are implemented (Anthony and Hunter 2017).

\section{Examples from initial teacher education programmes}

In the following section, we provide two examples of the ways in which the conceptual model we have described can be applied to initial teacher education programmes. The purpose of the examples is to illustrate the interrelationships among initial teacher education and the other systems that surround student learning outcomes, the ways in which initial teacher education intersects with these systems, and the impact on students of elements of initial teacher education other than teacher candidates. The examples are deliberately taken from two contrasting initial teacher education programmes from two states in Australia. The first is a post-graduate initial teacher education programme and the second is an undergraduate initial teacher education programme. 
In 2008, the Melbourne Graduate School of Education (MGSE) introduced a Master of Teaching programme as part of broader University of Melbourne curriculum reform which consolidated undergraduate degrees and charged newly formed graduate schools (such as Education, Law, and Medicine) with professional preparation. The Master of Teaching was inspired by initial teacher education programmes in the United Kingdom (Benton 1990), and the United States (Hammerness and DarlingHammond 2002) which utilised and adapted clinical models of pre-service teacher education. A hallmark of these of these programmes is the breakdown of the traditional theory/practice divide. This is achieved through substantial time spent in schools, the movement of school and university staff across the sites of practice, and the design of pre-service curriculum and assessment that bring together university and school experiences in a way that prepares pre-service teachers for the complex task of teaching (Alter and Cogshall 2009; Burn and Mutton 2013). These programme features lead to impacts in the programme's partner schools from teacher educators, teacher education research and the teacher education programme as a whole, as well as from teacher candidates and graduates of the programme.

In terms of the MGSE Master of Teaching, pre-service teachers across early childhood, primary and secondary programmes spend two days a week in schools, and three on site at the university. When in schools, pre-service teachers are supported by a senior member of staff drawn from one of the key partner schools called a Teaching Fellow. This .5 role is paid by the university (the remainder of the teaching position is paid by the school) and works to support pre-service teachers across multiple sites to understand and negotiate school cultures and expectations, and to support Mentor Teachers who are working with pre-service teachers. Teaching Fellows work closely with an academic colleague called a Clinical Specialist, a university staff member who is in schools one day a week, and who is charged with supporting pre-service teachers to link theory and practice. Together, Clinical Specialists and Teaching Fellows support pre-service teachers to prepare for assessment and gather data and evidence on student learning from schools, and ensure consistency and quality of experiences for pre-service teachers in the programme (for further details, see McLean Davies et al. 2017; Redman 2014; Ure 2010). Additionally, both Teaching Fellows and Clinical Specialists often provide professional learning for in-service teachers in schools and early childhood settings. This means that this programme reflects and supports a networked and complex understanding of the ways in which initial teacher education impacts on student learning similar to the model shown in Figure 1. The learning-focused relationships between Clinical Specialists and Teaching Fellows are an example of the impact of teacher educators in schools (Figure $5)$. 
The following example, chosen to illustrate the model of complex and interrelated impacts proposed in this paper, draws on previous collaborations undertaken between academics and leading teachers at Koonung Secondary College (McLean Davies et al. 2013). Koonung is a large coeducational secondary school in the eastern suburbs of Melbourne with approximately 1000 students from Year 7 (which typically 12 years of age) to Year 12 (typically 18 years of age). Since the Master of Teaching programme began in 2008, Koonung has hosted more than 200 MGSE teacher candidates, and in 2015, approximately one third of the Koonung teaching staff were graduates of the Master of Teaching. Wright, the then principal of Koonung Secondary College reported that "there is no doubt that [the Master of Teaching] programme has delivered improved student outcomes at Koonung, the data around student relationships, well-being and teaching and learning shows this" (cited in McLean Davies et al. 2017, p. 220).

Notably, Wright refers to the Master of Teaching programme as a whole as having the impact on student learning (Figure 6), rather than limiting this to the interventions of pre-service teachers (even though graduates are clearly valued and employed by the school on the completion of the programme). The reflections of Jane Thornton, who was first a Mentor Teacher, and later a Teaching Fellow at Koonung, provide some insights into different and circuitous ways in which the programme impacts on student learning. Thornton notes that, in working with pre-service teachers, she is conscious of the models of instruction she is providing: "I try to make my teaching as visible as possible by explaining what I am doing and why. I use the same language and theories covered at university" (cited in McLean Davies et al. 2017, p. 217). Adopting a shared language has been a key imperative in the Master of Teaching, and we see here that Thornton's practice, discourse and knowledge has been impacted by her involvement in and contribution to the Master of Teaching programme. Clearly, while pre-service teachers will benefit from Thornton's explicit and careful mentoring, her increased cognisance of her own teaching praxis will of course affect the students in her secondary health and physical education classes. Developing shared language is a way in which initial teacher education programmes as a whole impact schools and student learning.

Indeed, the impact of the Master of Teaching on in-service teacher practice and student learning was reflected in the desire of Koonung staff to undertake further mentoring training and develop a greater understanding of clinical teaching. In 2011-2012, MGSE and Koonung were awarded federal government funding to form a School Centre for Teaching Excellence (DET). A key initiative of this project was to develop a Specialist Certificate in Education-Clinical Teaching, available to Koonung Mentor Teachers and Mentor Teachers in surrounding partner schools.. While the Specialist Certificate ensured Mentor Teachers at Koonung were well prepared to support pre-service teachers, their participation in this accredited professional learning also influenced their approaches to learning and teaching in their own classrooms. In a complexity framework, these activities are more than 'spin offs' from the original activity 
of partnering to provide initial teacher education, they are emergent outcomes that are evidence of initial teacher education's impact on schools and the learning of the students within them. Significantly, participants in this course at Koonung initiated a 'praxis' group at the conclusion of their subjects in order to continue exploration of and reflection on their teaching, and have published the results of their action research in teacher professional journals. In this example, the initial teacher education programme can be seen to impact in-service teachers' professional knowledge, and their use of and contribution to research just as Figure 7 proposes.

Jane Thornton, who undertook the Specialist Certificate and was a founding member of the praxis group, claims that the Master of Teaching programme has transformed learning and teaching at Koonung. Thornton's account of the impact of the programme on teachers resonates with Clinical Specialist Barbara Hadlow's experience. Hadlow writes that, in the Master of Teaching at Koonung, "[p]rofessional development has become reciprocal. Teaching and learning is broadly impacted, and the schools and university are deeply enmeshed in the transactions" (cited in McLean Davies et al. 2017, p. 216). A community of practice that spans the school and the university, and is centred around teacher education but not limited to the ways in which pre-service teachers are prepared, has been created. The impact on student learning Wright refers to, then, cannot be traced to a single source.

Indeed, it is important to acknowledge that the ways in which initial teacher education can impact on school cultures is affected by forces both within and outside school and university partnerships including funding to support the high cost of clinical models of ITE. It is possible to provide many examples of the ways in which the Master of Teaching curriculum has been taken up in schools that partner with the university in this programme - one notable example is the ways in which the clinical practice exam, a central assessment task that draws together academic subjects and school practice, has been adapted by schools for professional learning (Kameniar et al. 2017). It is certainly the case that the scope and strength of impacts on student learning made possible through initial teacher education are affected by a range of variables, including policy and resourcing, which are often outside the remit of teacher educators.

\section{Example 2: Sydney, NSW}

The final year of The Bachelor of Education (Primary) degree at the University of Sydney includes a first semester unit of study that teaches content and pedagogic knowledge relevant to the Australian English Curriculum. A discussion-based strategy called Literature Circles is embedded in this unit. Literature circles are a dialogic tool that help students develop personal, critical and aesthetic responses and engage with literary texts through reflective discussion (Daniels 1994). 
Dialogic teaching (Alexander 2017) was first introduced to these initial teacher education candidates in 2006 through research undertaken by the teacher educator in charge of the unit of study. The researchinformed teaching practice has subsequently had impact on multiple cohorts, teachers and school students, leading to improved learning for all three groups. This example explains how the interwoven nature of learning involving teacher educators, teacher candidates, teachers and students in primary schools has led to the emergence of productive relationships as well as the exchange of knowledge across the levels of the proposed conceptual model (Figure 1).

Putting the Literature Circle work in the context of the whole degree, the teacher educator's aim in employing dialogic pedagogy in a final year unit about the teaching of English is to position teacher candidates in the dual roles of reader and teacher of reading, provoking their critical understanding of literary texts and reflective meta-awareness of the function of dialogue in learning (Simpson 2016). Research-informed and research-led approaches to teaching in the Bachelor of Education degree require teacher candidates to investigate and report on their practice. Therefore, all final year teacher candidates devise a professional learning project through which they gather evidence of the impact of their teaching on student learning and situate it in a body of scholarly literature. In this initial teacher education context the teacher candidates are directly examining their impact on student learning. All teacher candidates work with critical friends who moderate annotated work samples and provide peer feedback on video excerpts of teaching. As project designs must be discussed both with teacher educators and teacher mentors to appropriately match teacher candidate needs and syllabus requirements, the teacher candidate needs to negotiate the requirements of initial teacher education in dynamic interaction with school policy. The course requirement also brings the ideas of the teacher educator and the teacher education programme into dialogue with the schools' practices, allowing initial teacher education to impact the school through sharing research and through teacher educator relationships.

It is in this context that the implementation of Literature Circles is explored as a case where the potential impact of initial teacher education across the education system can be tracked. In 2015 one teacher candidate chose Literature Circles as the focus of her professional learning project working with a Stage 3 (Year 5/6) class of primary school students and their teacher. As a result of discussions held between the teachers, the teacher candidate and the teacher educator about the benefits of the pedagogy on student learning, other teachers became interested in shadowing the Literature Circles project. The teachers and teacher candidate formed a collegial inquiry group and sought advice from the teacher educator on ways to improve their practice. The teacher educator became a critical friend who encouraged the teachers to use research to build their professional knowledge of dialogic teaching. The involvement of the teacher educator illustrates the ability of teacher educators to impact on schools and student learning (Figure 5). The schools reported improvement in students' talking and listening, and also in comprehension, critical and interpretive responses to literary texts as well as meta-awareness of learning (Simpson 2017). 
The impact of initial teacher education on learning could have remained uni-directional and contained within the school classrooms. However, with ethical permission granted, video recordings were made of school students' reflective commentary about Literature Circles. These videos were shown to the school students who critiqued their own discussions, which deepened their learning outcomes. The educational influence of the videos continued to develop as they were shared with the school community during Education Week and in parent/student interviews. Videos were also made of interviews with the teacher candidate and the other teachers who had taken up the strategy, reflecting on their practice. The full set of videos were edited and repurposed as the basis of an open access professional development resource which is now hosted on the teacher educator's website, https://www.filmpond.com/ponds/sydneyuni/films/literature-circles, further breaking the boundaries between schools and the wider education system. The value of the partnership with initial teacher education is captured in a statement by the lead literacy teacher who reflects on the impact the interactions had on the primary school students and their teachers: "when students shared in the past there was no deep discussion. Now all students want to participate in a discussion and it gives the teacher ongoing opportunities to assess through formative assessment". These ideas were brought to the school through engagement with initial teacher education, through teacher candidates (Figure 4) and teacher educators (Figure 5).

Later the same year, at the end of the university semester, a professional partnership evening was held at the university, attended by teachers and school principals from across the sectors in which teacher candidates are placed by the university. As a strong modelling of the productive partnership that had been set up by the initial teacher education programme and then brokered between teacher educator, teacher candidate and the school, perspectives on the impact of using dialogic teaching on student learning were presented by the teacher candidate, the lead literacy teacher and the university educator. This work both used education research and fed back into education research (Figure 7). The teacher candidate described the uptake of the pedagogy in terms of how it made changes to her students' English outcomes and their confidence as learners. The experienced teacher described how the sharing of the pedagogy with other staff had led to professional development in the school. The teacher educator described how examples of dialogic teaching videoed in the school classrooms during professional experience had been fed back into the lecture series at the university informing a new cohort of teacher candidates.

Subsequent to this one-off event, the impact of initial teacher education has spread to education research more broadly. On request from some school leaders who attended the professional partnership evening, the information was presented in other school contexts, leading to further professional development. Some of these invitations led to small research studies where teachers chose to investigate their own 
practice with dialogic teaching as part of professional requirements. In all cases the teacher educators worked as a critical friend in professional learning partnerships with the teachers. The findings from these studies have since led to a new round of professional development staff meetings as well as a number of publications, which are being shared at national and international levels through professional and academic publications and national and international conference presentations (Jones et al. 2018). This iterative cycle of dialogic teaching embedded in initial teacher education has now had an impact on many teachers, students and other teacher education programmes where teachers made space in their timetables for exploratory learning. It has helped teachers, schools and parents gain new insight into student learning processes. Despite having no funding, the research interests of one teacher educator as part of an evidence-based initial teacher education programme have now been taken up by three different education sectors.

\section{Conceptualising the Impact of Initial Teacher Education}

These two brief examples serve to illustrate the potential of widening our notion of impact from initial teacher education. Work which may have seemed peripheral to the core business of educating new teachers can be seen, using the conceptual model proposed here, to be integral to educating new teachers within a system that also learns and grows. By applying the model to examples such as these we can get a sense of what might be lost if initial teacher education no longer involved tertiary institutions. Beyond this, though, we can also see the necessity for evaluation of initial teacher education impact to include multiple metrics from different layers of the system. To understand the impact of initial teacher education, a range of questions needs to be asked: to what extent is school involvement with initial teacher education leveraging changed practice in the school context? To what extent are certain initial teacher education practices (such as weekly placements) influencing policy makers and regulators' decisions about initial teacher education programmes? How is research by teacher educators being used in schools and in initial teacher education? What are the impacts of new relationships formed between teacher educators and teachers and leaders in schools?

Three concepts from complexity thinking can help us understand why initial teacher education might have impacts on student learning through these multiple routes. First, we see initial teacher education as a complex system, and as part of the broader complex system of education. Complex systems do not function in linear ways (Davis and Sumara 2006; Cochran-Smith et al. 2014). Multiple interactions and interdependencies mean that direct causal models do not adequately describe the way things happen. Thus, as in the Sydney example, a seemingly small event (a student undertaking an assignment) can have large consequences (a number of schools collaborate to introduce a new, more effective, literacy practice). Initial teacher education provides a stimulus to the education system that can potentially trigger events such as this, through the mechanism of amplification within the system, where feedback loops 
increase the occurrence of certain phenomena. In the Sydney example, the Literature Circles were picked up by nearby teachers, whose interest and success prompted others to try them too. Placing teacher candidates in classrooms can thus be a catalyst for improved classroom or school practices, and there is an opportunity for us to research and learn more about how this can happen if we recognise the full impact of placement/partnership arrangements in our evaluation of initial teacher education effectiveness (Grudnoff et al. 2017).

Second, complexity thinking introduces the idea of emergence: a system is in a constant state of growing and changing as part of its nature, and what it 'produces' is emergence, a current state of being that will shift and change (Davis and Sumara 2006). This contrasts with a mechanistic, factory-like metaphor where teachers with certain qualities are 'produced'. Through this lens, the function of initial teacher education is to increase the emergence of practice that makes a difference to student learning. This automatically suggests a broader field of influence than just teacher candidates' practice and introduces a new agenda for understanding what is emerging and what the mechanisms are that have led to that emergence. The Melbourne example emphasises the role that new professional relationships can play in influencing practice, and the ways in which involvement in the pre-service programme can impact on school culture and student learning more broadly. It also points to the importance of policy and resourcing decisions which enable the rich and variable impacts of initial teacher education to be mobilised and experienced.

The third concept from complexity thinking is the role of neighbours in a system. Initial teacher education's role in introducing ideas and people into the system can make change. The Melbourne example illustrates how placing people together in close relationship (an initial teacher education programme feature at MGSE) leads to the emergence of practice that makes a difference to student learning through multiple interactions and increasing interdependence and merging of roles. Complex systems are driven by interactions between neighbours, and these neighbours can be people or things, but they can also be ideas. Diverse ideas coming up against each other produce rich interactions in the right conditions, and promote emergence. The Sydney example shows how an idea can 'travel', in some cases just next door and in others globally, and new practice can emerge when the idea meets the right conditions.

\section{Conclusion and implications}

In this paper we have argued that narrow, process-product conceptions of the impact of initial teacher education, focused solely on graduate teachers' students' achievement, miss important ways in which initial teacher education functions as part of the wider education system. The conceptual model described and exemplified here is an attempt to tease out some of these additional influences and to suggest that evaluating the effectiveness of initial teacher education should include taking a broad view of its 
contributions to the education system and to student learning. This argument has implications for research, practice and policy.

\section{Research}

Research about initial teacher education has not yet provided an evidence base that policy makers find compelling (Mayer et al. 2017; Sleeter 2014; Murray et al. 2008; Rowan et al. 2015), and yet there is a growing body of empirical work which begins from the premise that initial teacher education is non-linear. Using a model such as the one suggested here opens up new research agendas and provides a way to aggregate and use findings from small or disparate studies.

\section{Practice}

At a basic level, the model could help initial teacher education providers to structure more holistic evaluations of their work and to provide evidence of impact that values their activity more fully and more cohesively than current models. It could also serve to highlight areas for development and to encourage deliberate development of relationships, research and programme structures that are designed to impact learning throughout the system. Another affordance of the model is to suggest areas in which initial teacher education may not be making the most of its potential to impact student learning. In devising the model, we discussed the interaction between initial teacher education and communities and families. This is an area which has been pursued by some initial teacher education programmes with positive effects (Guillen and Zeichner 2018; Zeichner et al. 2015) and could be further developed by Australasian programmes.

Policy

Policy is perhaps the area for which this model has the most significant implications. While policy remains focused narrowly on teacher candidates' performance as the measure of initial teacher education's impact, it neglects the other ways in which initial teacher education is working to impact student learning (Comber 2012). We argue that we should look not only at what teacher candidates know and can do when they graduate from initial teacher education (Furlong 2015), but also that we should look at the impact of programmes, teacher educators and education research on schools, leaders, teachers and students in order to capture as much as we can of the complex ways in which initial teacher education intersects with schooling. This may lead to the identification of different policy levers, or the discovery of innovative ways to invest in teacher preparation that will benefit learners and the education system as a whole.

\section{References}

Alexander, R. (2017). Towards dialogic teaching: Rethinking classroom talk (5th ed.). Cambridge: Dialogos. 
Alter, J., \& Coggshall, J.G. (2009). Teaching as a clinical practice profession: Implications for teacher preparation and state policy. New York: National Comprehensive Centre for Teacher Quality. http://www.tqsource.org/publications/clinicalPractice.pdf.

Anderson, R., Crabtree, B., Steele, D., \& McDaniel, R. (2005). Case study research: The view from complexity science. Qualitative Health Research, 15(5), 669-685.

Anthony, G., \& Hunter, R. (2017). Grouping practices in New Zealand mathematics classrooms: Where are we at and where should we be? New Zealand Journal of Educational Studies, 52(1), 73-92.

Australian Institute of Teaching and School Leadership (2015). Accreditation of initial teacher education programmes in Australia: Standards and procedures. Melbourne: AITSL.

Benton, P. (Ed.) (1990). The Oxford internship scheme: Integration and partnership in initial teacher education. London: Calouste Gulbenkian Foundation.

Burn, K., and T. Mutton. (2015). A review of "research-informed clinical practice" in initial teacher education. Oxford Review of Education, 41(2), 217-233.

Byrne, D. (1998). Complexity theory and the social sciences. London: Routledge.

Cilliers, P. (1998). Complexity and postmodernism: Understanding complex systems. London: Routledge.

Cochran-Smith, M., Ell, F., Ludlow, L., Grudnoff, L., \& Aitken, G. (2014). The challenge and promise of complexity theory for teacher education research. Teachers College Record, 116(5), 1-38.

Cochran-Smith, M., Stern, R., Sánchez, J.G., Miller, A., Keefe, E.S., Fernández, B., Chang, W-C., Carney, M. C., Burton, S., \& Baker, M. (2016). Holding teacher education accountable: A review of claims and evidence. Boulder, CO: National Education Policy Center.

Cochran-Smith, M., \& Villegas, A. (2015). Framing teacher preparation research: An overview of the field, Part 1. Journal of Teacher Education 66(1), 7-20.

Cochran-Smith, M., \& Zeichner, K. (2005). Studying teacher education: The report of the AERA Panel on Research and Teacher Education. Mahwah, NJ: Lawrence Erlbaum Associates. 
Coggshall, J. G., Bivona, L., \& Reschly, D. J. (2012). Evaluating the effectiveness of teacher preparation programs for support and accountability. Washington, DC: National Comprehensive Center for Teacher Quality.

Comber, B. (2012). Mandated literacy assessment and the reorganisation of teachers' work: Federal policy, local effects. Critical Studies in Education, 53(2), 119-136.

Comber, B., \& Freebody, P. (2013). Literacy education in a changing policy environment: Introduction. Australian Journal of Language and Literacy, 36(2), 65-66.

Cormack, P., \& Comber, B. (2013). High stakes literacy tests and local effects in a rural school. Australian Journal of Language and Literacy 36(2), 78-89.

Council for the Accreditation of Educator Preparation (2018). CAEP Handbook Initial-Level Programs 2018. Washington DC: CAEP.

Daniels, H. (1994). Literature circles: Voice and choice in the student centred classroom. Portland, MN: Stenhouse Publishers.

Darling-Hammond, L. (2015). Can value added add value to teacher evaluation? Educational Researcher, 44(2), $132-137$.

Davis, B., \& Sumara, D. (1997). Cognition, complexity and teacher education. Harvard Educational Review, 67(1), 105-127.

Davis, B., \& Sumara, D. (2006). Complexity and education: Inquiries in learning, teaching, and research. New York: Routledge.

Davis, B. \& Sumara, D. (2010). If things were simple...: complexity in education. Journal of Evaluation in Clinical Practice, 16, 856-860.

Day, C., \& Gu, Q. (2014). Resilient teachers, resilient schools: Building and sustaining quality in testing times. London: Routledge.

Department for Education (2013). Teachers' standards: Guidance for school leaders, school staff and governing bodies. Department for Education. UK Reference: DFE-00066-2011. 
Education Council of New Zealand (2016). Strategic options for developing future orientated initial teacher education. Wellington: Education Council of New Zealand.

Ellis, S., \& Moss, G. (2014). Ethics, education policy and research: The phonics question reconsidered. British Educational Research Journal, 40(2), 241-260.

Elmore, R.F. (2016). "Getting to scale ..." it seemed like a good idea at the time. Journal of Educational Change, 17(4), 529-537.

Fullan, M. (2016). The elusive nature of whole system improvement in education. Journal of Educational Change, 17(4), 539-544.

Furlong, J. (2015). Teaching tomorrow's teachers: Options for the future of initial teacher education in Wales: A report to Huw Lewis, AM, Minister for Education and Skills. Retrieved from http://gov.wales/docs/dcells/publications/150309-teaching-tomorrows-teachers-final.pdf.

Gillis, S., Polesel, J., \& Wu, M. (2016). PISA data: Raising concerns with its use in policy settings. Australian Educational Researcher, 43(1), 131-146.

Grossman, P., \& McDonald, M. (2008). Back to the future: Directions for research in teaching and teacher education. American Educational Research Journal, 45(1), 184-205.

Grudnoff, L., Haigh, M., \& Mackisack, V. (2017). Re-envisaging and reinvigorating school-university practicum partnerships. Asia-Pacific Journal of Teacher Education, 45(2), 1-14.

Guillen, L., \& Zeichner, K. (2018). A university-community partnership in teacher education from the perspectives of community-based teacher educators. Journal of Teacher Education, 69(20), 140153.

Hammerness, K., \& Darling-Hammond, L. (2002). Towards a pedagogy of cases in teacher education. Teaching Education, 13(2), 125-135.

Hayes, D., \& Doherty, C. (2017). Valuing epistemic diversity in educational research: An agenda for improving research impact and initial teacher education. Australian Education Researcher, 44(2), 123-139.

Hetherington, L. (2013). Complexity thinking and methodology: the potential of 'complex case study' for 
educational research. Complicity, 10 (1/2), 71-85.

Jones, P., Simpson. A., \& Thwaite, A. (2018).Talking the talk: Snapshots from Australian classrooms. Marrickville: PETAA.

Kameniar, B., McLean Davies, L., Reid, C., Tyler, D., \& Acquaro, D. (2017). Clinical praxis exams: Linking academic study and professional practice knowledge. In M. Peters, B. Cowie \& I. Menter (Eds.), A companion to research in teacher education (pp. 53-68). Dordrecht: Springer.

Loeb, S., \& Candelaria, C. A. (2012). How stable are value-added estimates across years, subjects and student groups? What we know series: Value-added methods and applications. Knowledge brief 3. Stanford, CA: Carnegie Foundation for the Advancement of Teaching.

Mason, M. (2008). (Ed.). Complexity theory and the philosophy of education. West Sussex, UK: Wiley Blackwell.

Mayer, D., Cotton, W. \& Simpson, A. (2017). Teacher education in Australia: Evidence of effectiveness. In J. Lampert (Ed.), The Oxford Encyclopedia of Critical Perspectives on Teacher Education. Oxford University Press. Retrieved from DOI: 10.1093/acrefore/9780190264093.013.305.

Mayer, D., Pecheone, R., \& Merino, N. (2012). Rethinking teacher education reform in Australia: The teacher quality reforms. In A. Lieberman and L. Darling-Hammond (Eds.), Teacher education round the world: Changing policy and practices (pp. 110-129). London: Routledge.

McLean Davies, L., Angelico, T., Hadlow, B., Kriewaldt, J., Rickards, F., Thornton, J., Tuckerman, B., \& Wright, P. (2017). Supporting the development of the profession: The impact of a clinical approach to teacher education. In G. Savage and T. Bentley (Eds). Educating Australia: Challenges for the decade ahead (pp. 209-226). Melbourne: Melbourne University Press.

McLean Davies, L., Dickson, B., Rickards, F., Dinham, S., Conroy, J., \& Davis, R. (2015). Teaching as a clinical profession: Translational practices in initial teacher education - an international perspective. Journal of Education for Teaching, 41(5), 514-528.

McLean Davies, L., Anderson, M., Deans, J., Dinham, S., Griffin, P., Kameniar, B., Page, J., Reid, C., Rickards, F., Tayler, C., \& Tyler, D. (2013). Masterly preparation: Embedding clinical practice in a graduate pre-service teacher education programme. Journal of Education for Teaching, 39(10), 93106. 
Menter, I., Hulme, M., Elliot, D., \& Lewin, J. (2010) Literature review on teacher education in the $21^{\text {st }}$ century. Edinburgh: The Scottish Government.

Meyer, H.D. (2013). OECD's PISA: A tale of flaws and hubris. Teachers College Record. December 19, 2013.

Morrison, K. (2008). Educational philosophy and the challenge of complexity theory. In M. Mason (Ed.), Complexity theory and the philosophy of education (pp. 16-31). West Sussex, UK: Wiley Blackwell.

Murray, S., Nuttall, J., \& Mitchell, J. (2008). Research into initial teacher education in Australia: A survey of the literature 1995-2004. Teaching and Teacher Education, 24(1), 225-239.

Ovens, A. (2017). Putting complexity to work to think differently about transformative pedagogies in teacher education. Issues in Teacher Education, 26 (3), 38-51.

Polesel, J., Dufler, N., \& Turnbull, M. (2012). The experience of education: The impacts of high stakes testing on school students and their families. Sydney: Whitlam Institute, University of Western Sydney.

Redman, C. (2014). The Melbourne Graduate School of Education Master of Teaching: A clinical practice model. In M. Jones and J. Ryan (Eds.), Successful teacher education: Partnerships, reflective practice and the place of technology (pp. 11-30). Rotterdam: Sense Publishers.

Rowan, L., Mayer, D., Kline, J., Kostogriz, A., \& Walker-Gibbs, B. (2015). Investigating the effectiveness of teacher education for early career teachers in diverse settings: The longitudinal research we have to have. Australian Educational Researcher, 42(3), 273-298.

Simpson, A. (2016). Dialogic teaching in the initial teacher education classroom: "Everyone's voice will be heard". Research Papers in Education, 31(1), 89-106.

Simpson, A. (2017). Teachers negotiating professional agency through literature-based assessment. Literacy, 51(2), 111-119.

Sleeter, C. (2014). Toward teacher education research that informs policy. Educational Researcher, 43(3), 146-153. 
Timperley, H., Kaser, L., \& Halbert, J. (2014). A framework for transforming learning in schools: Innovation and the spiral of inquiry. Melbourne: CSE.

Ure, C. (2010). Reforming teacher education through a professionally applied study of teaching. Journal of Education for Teaching, 36(4), 461-475.

Waks, L. (2011). Teacher education programs as complex organizations. Emerging Changes in Teacher Education, 8(1), 65-69.

Zeichner, K., Payne, K., \& Brayko, K. (2015). Democratizing teacher education. Journal of Teacher Education, 66(2), 122-135. 